\title{
INFORMATION TECHNOLOGY AND ROMANIAN HIGHER EDUCATION - EVIDENCE ON LINKED DYNAMIC
}

\author{
Bogdan Nichifor \\ "Vasile Alecsandri" University of Bacău \\ bnichifor@gmail.com
}

\begin{abstract}
The link between education, in general, and information technologies is one that does not necessarily have to be demonstrated. But it is interesting to see the specific link that is established between these two components of modern society. In recent years, part-time education forms tend to occupy an increasingly important position in the Romanian higher education from the perspective of the total number of students opting for distance learning or traditional part-time learning. This development occurred amid expansion of information technology - more and more households have Internet access and frequency of its use is increasing from year to year - in the context in which forms of part - time learning require the use of this means of information and communication. On this background more and more people over 25 years become interested in further developing their studies, including employed persons opting for further studies, increasing the share of students over 25 years in total students and the share of employed population over 25 years with higher education in total in respective age group.
\end{abstract}

\section{Keywords}

tertiary education; part-time education; information technology; access to internet; employed population

\section{JEL Classification}

M30

\section{Objectives}

In the context of accelerated progress of information technology and the growing pressure of employers for highly educated and skilled workers it is interesting to view how the higher education is linked with the evolution and use of information technology. Development and widespread use of information technology in Romania has enabled emergence of distance learning and traditional part-time learning, targeting persons whose activities do not allow following courses with frequency. Thus, more and more people, including employed population, continue their education by enrolling in higher education after 25 years.

This article aims to highlight some of the main factors influencing the development and widespread use of information technology in Romanian higher education. For this purpose it was intended to identify the evolution over time in part-time education and its place in higher education as a whole, the degree of access of the general public, especially of the employed population, to higher education throughout life, while highlighting the use of information resources.

\section{An overview on education - information technology links}

Both in Europe and in Romania, integrating information technology into the formal education system is a result of economic and social environment requirements. 
The dynamic of technological development was the expansion factor of the formal continued education system. In the past 10 years, we have seen a significant increase in the number of adults who have returned to formal education system in order to expand areas of expertise, or to develop new skills. In this sense, at first glance, we might consider that the exodus of adults returning to formal education is a direct consequence of increased qualified workforce demand manifested by companies stimulated by the pressure for productivity of the global economy. This assessment is based, on the one hand, on the high number of transnational which have expanded their operations in Romania and, on the other hand, on the tendency of alignment with global practices exhibited by local organizations. In this direction, we may mention the efforts made by organizations in various sectors towards improving skills related to human resources. Assuming that the quality of the workforce is the key component in increasing productivity and efficiency of a company, many local and transnational organizations have started investing in human resources training programs (Badescu and Deji, 2004). This phenomenon was highly visible, at least until the end of 2008, in areas such as banking and financial services, insurance, provision of utilities (water, gas, and electricity), catering etc. This has forced the return of the adults into the formal education system in order to obtain the necessary job qualifications.

If in Romania the interest to study the development by continued study is recent, the global and European literature granted since the end of the twentieth century a particular importance to researches aimed to study the impact of information technology on long-term educational process. In this respect, Friedman in an article published in 1999 said that "the involvement of information technology in education will be the second largest application after the Internet" (Friedman, 1999).

Many authors claimed, at the same time, that the rapid development of Web technology has favored the emergence of platforms to support distance education process. The usability of hypermedia web-based materials provided appropriate framework to create a new formal learning environment that supports a wide variety of interactive activities (Paquette et al., 1995). Based on its fundamental characteristics - simultaneity, interactivity and direct feedback - the web promotes student - tutor interaction (Friedman, 1999) reducing, at least in perception, space problem in distance learning (Pei-Luen et al., 2005).

At the same time, President of SCI Solutions in Education and Training, Rodney Everhart, believed that the exodus of adults returning to studies will generate over the next 10 years an agglomeration of university-type education institutions, promoting the development of distance learning and on-line learning programs (Morrison, 1999). In fact, these two authors were advocates of extending the formal education system with on-line and distance learning, their arguments being both economic (reduced costs) and time and flexibility of approach related, and of course to associated with the changes imposed by economic globalization.

In the context of the proposed analysis is absolutely necessary a coherent delimitation of areas involving information technology in education. According to a report provided by the OECD in 2005, the integration of information technology in education knows many forms (OECD, 2005), as follows:

- Interrelated courses with information technology, which involves integrating in the traditional educational process the related instruments;

- Dependent course on information technology courses, which necessarily require integration tools for the traditional educational process;

- Mixed modules: increasing the share of educational activities in the online environment;

- E-learning courses, which involves running the educational process exclusively on line. 
The emergence of information technology in education, in its many forms, has been supported by Organization for Economic Cooperation and Development (OECD), this organization pointing toward main advantages: accessibility, flexibility, cost and quality (Kurt and Stéphan, 2005).

Divergent view compared to previous was provided by a teacher from Oregon University, Greg Bothun. According to the opinions of the author, the system of higher education should resist the temptation to become an entrepreneurship-led educational system, criticizing excessive focus on cost reduction (Bothun, 1999). In fact, according to this author, the expansion of the educational system in the online environment is supported, erroneously, by the consideration that the word knowledge is synonyms with the word information. It should be noted that the author does not address the importance of integrating information technology in learning, but its status as a training instrument.

While the global and European educational system focused on developing study programs in the online environment, in Romania increased demand for adult education services was satisfied by developing distance learning programs within public universities, on the one hand, and within private universities, on the other hand. In fact, distance education is the one that has experienced the fastest growing and most extensive presence because it is the only form of learning designed to be based on "a large social applicability of electronics, computer, internet and other derivatives” (Tomescu, 2008).

Developing curricula in the online environment has not evolved similar to that in global developed systems, barriers in this respect being: low number of households with PCs, low number of households with Internet access, low level of population interest in following online studies etc. In this context, in the year 2010, 58\% of universities in Romania used eLearning solutions in teaching and similar activities, and among those not using such solutions, 68\% said that they intend to develop such systems in the near future (Crahmaliuc, 2010).

Another factor that favored the development of ICT based training, both globally and nationally, is the government policy. The governments of most states in Europe and worldwide, encourages lifelong learning which is considered a viable instrument that boost productivity and stimulate progress in the labor market. Reaching the most common macroeconomic objective - sustainable economic growth - can be done, according to foreign literature studies, by increasing productivity through absorption of more productive equipment, a better prepared workforce and creating new knowledge (Stiglitz, 2002).

Integrating ICT into the education system brings forward a new concept, "the knowledge economy", based on "knowledge, creativity, innovation and entrepreneurship" (Kozma, 2005). Much of the literature consider that an important pillar of the new economy is the continued education and this claim is supported by the reality of developed countries - knowledge-based economies - which are built on innovation and a strong education system.

To support the above, it may be mentioned approach started in the year 2007 by the World Bank, to promote the four pillars in the development of knowledge-based economies (World Bank, 2005).

- Encouragement of the population for education in order to create, share and use knowledge in continuous improvement of process skills;

- A modern information infrastructure capable to facilitate the effective communication, dissemination and processing of information and knowledge;

- A strong innovation system created from companies, research centers, universities and other stakeholders, with the role of supporting the sustainable development of the knowledge economy; 
- An institutional policy and a coherent set of economic decisions that stimulate resource mobilization and entrepreneurship in the dissemination and use of knowledge.

Although Romania is making small steps to align with European practices, the efforts made in this direction must be appreciated, we refer here to the legal framework for promoting continued education (Order no. 353/2003 and 5202/2003 regarding the authorization by Ministry of Education of continuing education institutions, order $501 / 2003$ and 5253/2003 on the certification of trainers, National Strategy for Continued Professional Training, 2005-2010 Short and Medium Term Strategy for Continued Professional Training, National Action Plan for Employment, 2006-2010 National Reform Plan, 2007-2013 National Development Plan, 2007-2013 Strategic Reference Framework, Operational Program - Human Resources Development and so on).

\section{Research methodology}

The work is a study based on secondary data sources, that statistical information from Eurostat and Romania National Institute of Statistics. We used last available official data disseminated through websites of listed institutions. We used in our analysis structure indicators and time series indicators, which have revealed the dynamics in part-time education and learning after the age of 25 years. We also used the structure and intensity indicators for highlighting access to information technology in the higher education institutions and the intensity of its use in households and by population.

According to the Eurostat methodology lifelong learning is directed toward people aged 25-64 years. Not having statistics for this population on the proportion of those who have pursued higher education, we used in our analysis the indicators that refer to the population over 25 years. The indicators refer to tertiary education - levels 5 and 6, accordingly to ISCED (International Standard Classification of Education the UNESCO 1997). Education level 5 refers to university education and the level 6 to postgraduate education (INSSE).

\section{Research results}

In recent years, in Romania, public access and frequency of use of specific means of information technology have increased considerably. Thus, during 2007 - 2013, the share of households owning computers increased from approximately $31 \%$ to over $55 \%$. Being directly dependent on the level of equipping of households with computers and Internet, the access to Internet also boomed from 14\% in 2006 to 58\% in 2013.

The level of usage has also witnessed an upward trend, so that the total population aged 16-74 years in 2013, 58\% used this means of information and communication, compared with $26 \%$ in 2006.

Table 1 PCs household facilities, Internet access and its use, in Romania between 2006 and 2013

\begin{tabular}{|cccc|}
\hline Year & $\begin{array}{c}\text { Households having } \\
\text { access to a computer, at } \\
\text { home - Percentage of } \\
\text { households** }\end{array}$ & $\begin{array}{c}\text { Households with } \\
\text { Internet access - } \\
\text { Percentage of } \\
\text { households*** }\end{array}$ & $\begin{array}{c}\text { Individuals* who have } \\
\text { ever used the Internet - } \\
\text { Percentage of } \\
\text { individuals*** }\end{array}$ \\
\hline 2006 & n.d. & 14 & 26 \\
2007 & 31.4 & 22 & 29 \\
\hline
\end{tabular}




\begin{tabular}{|llll|}
\hline 2008 & 35.0 & 30 & 33 \\
2009 & 42.2 & 38 & 38 \\
2010 & 44.2 & 42 & 43 \\
2011 & 46.8 & 47 & 46 \\
2012 & 52.0 & 54 & 52 \\
2013 & 55.8 & 58 & 58 \\
\hline
\end{tabular}

* Refers to population age from 16 to 74 years

Source: ** National Institute of Statistics - Tempo online (www.insse.ro), ***Eurostat

In 1999-2012 period, in Romania has been a significant increase in the number of students in part-time forms of higher education (except the last few years).

The number of students enrolled in first and second stage of tertiary education (levels 5 and 6) just in part-time forms recorded from 1999 to 2012 a dynamic that far surpasses the total number of students enrolled to these levels of education. In this context, the share of the number of students enrolled in part-time educational forms reported to the total number of students increased from about $13 \%$ in 1999 to over $17 \%$ in 2012 (in 2009 this indicator was 36,5\%). The year 2010 marks a general involution of the total number of students, including the part - time forms of education.

Table 2 Evolution of students in tertiary education - levels 5 and 6, the total and part-time forms in Romania from 1999 to 2012

\begin{tabular}{|cccc|}
\hline Year & $\begin{array}{c}\text { Total number } \\
\text { of students }\end{array}$ & $\begin{array}{c}\text { Students enrolled in } \\
\text { the part-time } \\
\text { education }\end{array}$ & $\begin{array}{c}\text { The share of students enrolled in part- } \\
\text { time education forms in total number of } \\
\text { enrolled students (\%) }\end{array}$ \\
\hline 1999 & 407.720 & 52.442 & 12,9 \\
2000 & 452.621 & 61.571 & 13,6 \\
2001 & 533.152 & 100.695 & 18,9 \\
2002 & 582.221 & 119.801 & 20,6 \\
2003 & 643.911 & 147.045 & 22,8 \\
2004 & 685.718 & 153.528 & 22,4 \\
2005 & 738.806 & 172.125 & 23,3 \\
\hline 2006 & 834.969 & 216.559 & 25,9 \\
2007 & 928.175 & 272.929 & 29,4 \\
2008 & 1.056 .622 & 378.839 & 35,9 \\
2009 & 1.098 .188 & 400.906 & 36,5 \\
2010 & 999.523 & 240.551 & 24,1 \\
2011 & 871.842 & 108.673 & 12,5 \\
2012 & 705.333 & 120.465 & 17,1 \\
\hline
\end{tabular}

Regarding the age structure of students in tertiary education (ISCED levels 5 and 6), there is an increase in the share of people over 25 years, the dynamics of the latter being well ahead the growth registered by the number of students in general (i.e. the increase is approximately 1.7 times for the total number of students and about 3 times for those over 25 years, in 1999-2012 period). This dynamic of the category of people aged over 25 years who are mostly employed (over $60 \%$ of population between 25 and 74 years was employed, in 2013, according to Eurostat data) has most likely has been possible because of easy access to online communication resources which thus allowed the development of those forms of education that did not involve continuous presence of student in specific learning locations. 


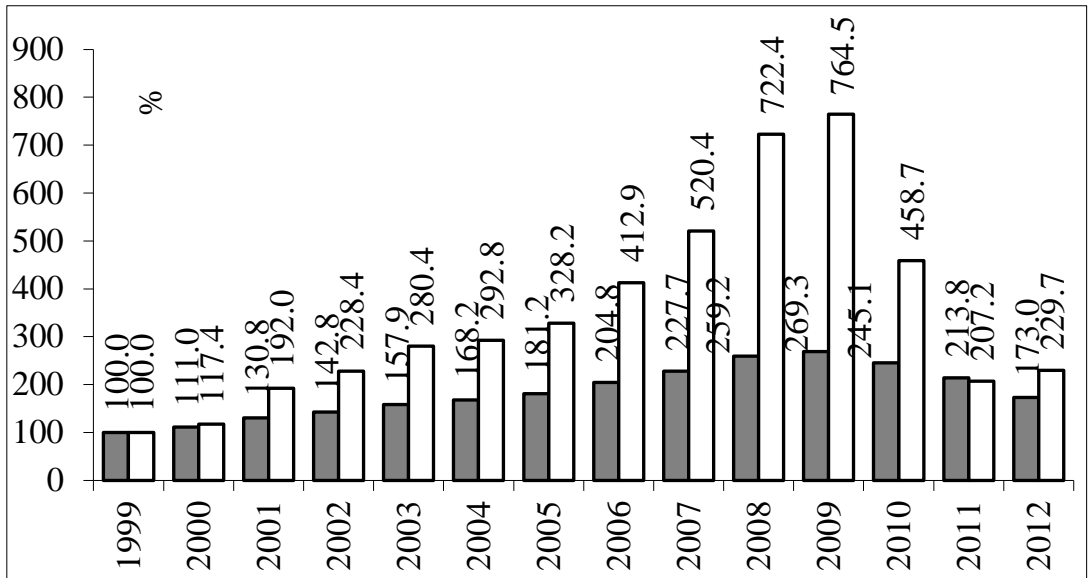

Total number of students $\square$ Students enrolled in the part-time education

Figure 1 Dynamics of students enrolled in tertiary education - levels 5 and 6, total and part-time in Romania from 1999 to $2012(1999=100 \%)$

Source: Adapted from Eurostat

Table 3 Evolution of students over 25 years old enrolled in tertiary education (ISCED levels 5 and 6) in Romania from 1999 to 2012

\begin{tabular}{|cccc|}
\hline Year & Students & $\begin{array}{c}\text { The share of students } \\
\text { over 25 years old in } \\
\text { total students (\%) }\end{array}$ & $\begin{array}{c}\text { The dynamics students } \\
\text { over 25 years old (\% } \\
\text { compared to 1999) }\end{array}$ \\
\hline 1999 & 71.406 & 17,5 & 100,0 \\
2000 & 76.209 & 16,8 & 106,7 \\
2001 & 97.735 & 18,3 & 136,9 \\
2002 & 115.540 & 19,8 & 161,8 \\
2003 & 161.817 & 25,1 & 226,6 \\
2004 & 184.847 & 27,0 & 258,9 \\
2005 & 213.974 & 29,0 & 299,7 \\
2006 & 261.322 & 31,3 & 366,0 \\
2007 & 310.334 & 33,4 & 434,6 \\
2008 & 358.104 & 33,9 & 501,5 \\
2009 & 403.886 & 36,8 & 565,6 \\
2010 & 370.361 & 37,1 & 518,7 \\
2011 & 286.500 & 32,9 & 401,2 \\
2012 & 210.555 & 29,9 & 294,9 \\
\hline
\end{tabular}

Confirming the idea presented above, the statistics reveal that in Romania the number of employed persons aged over 25 years (25-74 years), graduates 5 and 6 levels of education significantly increased along with the decrease in the total number of employed in this age category. It is evident, therefore, that the increase in the number of employed graduates took place as a result of the training period they were active at work (at least for some of them). In this context, the part-time learning through the use of specific technologies was undoubtedly a base in the educational process. 
Table 4 Evolution of the employed population between 25 and 74 years old, total and levels 5 and 6 graduate category in Romania from 1999 to 2013

\begin{tabular}{|cccc|}
\hline Year & $\begin{array}{c}\text { Employed population } \\
\text { between 25 and 74 } \\
\text { years old (thousands) }\end{array}$ & $\begin{array}{c}\text { Employment of 25 - 74 } \\
\text { years old population } \\
\text { graduated from tertiary } \\
\text { education (thousands) }\end{array}$ & $\begin{array}{c}\text { The share of employed } \\
\text { persons with higher } \\
\text { education in total employed } \\
\text { population of 25-74 years } \\
\text { old (\%) }\end{array}$ \\
\hline 1999 & $9.481,8$ & 891,6 & 9,4 \\
2000 & $9.411,2$ & 915,7 & 9,7 \\
2001 & $9.362,3$ & 980,9 & 10,5 \\
2002 & $8.555,9$ & 984,5 & 11,5 \\
2003 & $8.458,7$ & 942,3 & 11,1 \\
2004 & $8.349,9$ & $1.049,9$ & 12,6 \\
2005 & $8.286,3$ & $1.110,5$ & 13,4 \\
2006 & $8.509,8$ & $1.215,6$ & 14,3 \\
2007 & $8.573,6$ & $1.247,2$ & 14,5 \\
2008 & $8.593,0$ & $1.337,3$ & 15,6 \\
2009 & $8.491,6$ & $1.369,1$ & 16,1 \\
2010 & $8.519,0$ & $1.422,8$ & 16,7 \\
2011 & $8.461,5$ & $1.544,3$ & 18,3 \\
2012 & $8.618,0$ & $1.602,5$ & 18,6 \\
2013 & $8.642,7$ & $1.647,3$ & 19,1 \\
\hline
\end{tabular}

Source: Adapted from Eurostat

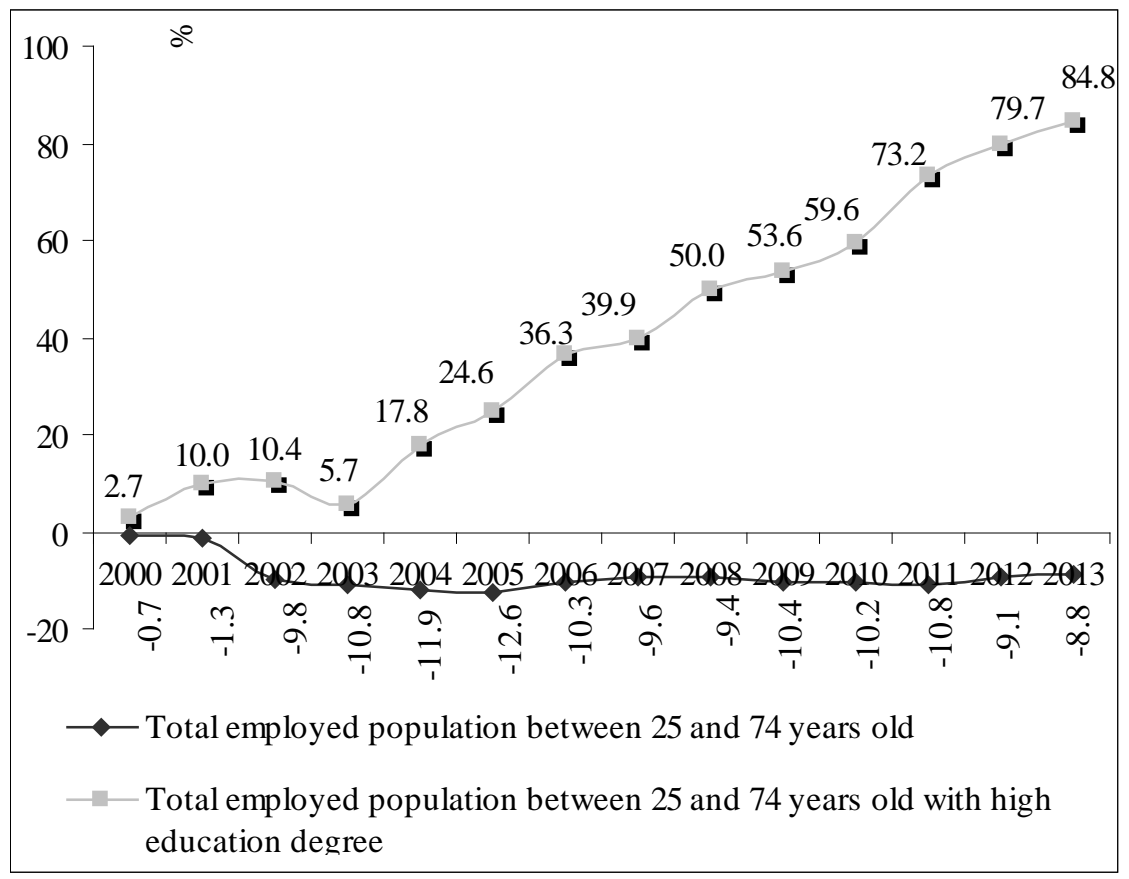

Figure 2 Occupied population dynamics of 25 to 74 years old, total and high education graduates in Romania from 1999 to $2013(1999=100 \%)$ 


\section{Conclusions}

The use of information technology in the tertiary education in Romania has generated the developing of different forms of distance and part-time learning and also made a significant contribution to the further intensification of education by pursuing higher education after the age of 25 years. Thus, there is an visible increase after 1999 (except the last few years) in the students number who are taking part in the forms of part time and distance learning with a growth rate which far exceeded the growth rate of the total number of students, in the same time with the sensible growth of the number of people over 25 years who are studying. These phenomena are in fact interdependent - the existence of the flexible forms of education in terms of training time and place has generated an increase in the demand for them among the employed, which resulted in the development of these forms of education because of the increasing number of students. On the other hand, the emergence and development of the forms of part time and distance learning are directly dependent on the development and use of information technology. In fact, for most of those who work and those who are in search for a job, further studies would not be possible in the traditional face-to-face education system because it implies the presence of students at certain times and in certain places.

\section{References}

Badescu, M. and Deji, A. (2004), Skills audit survey România, European Training Foundation.

Bothun, G. (1999), Cyberprof: The university in the next millennium, Educom Review, 34 (5), available at http:/www.educause.edu/ir/library /html/erm9954.html.

Crahmaliuc A. (2010), 58\% dintre universităţile din România utilizează soluţii de eLearning, Elearning Romania, 67, available at http://www.elearning.ro.

European Commission, EUROSTAT, available at http://epp.eurostat.ec.europa.eu.

Friedman, T.L. (1999), Next it's E-ducation, NEW York Times, available at http:/www.nytimes.com.

Gal-Ezer, J. and Lupo, D. (2002), Integrating Internet tools into traditional CS distance education: students' attitudes, Computers \& Education, 38 (4), 319329.

Kozma, R. (2005), National policies that connect ICT-based education reform to economic and social development, Human Technology, 1(2), 117-156.

Kurt, L. and Stéphan, V.L. (2005), The impact of ICT on tertiary education: advances and promises, Organisation for Economic Cooperation and Development (OECD), Michigan Conference "Advancing Knowledge and the Knowledge Economy” 10-11 January 2005, Washington DC.

Morrison, J.L. (1999), Higher education in 2010: An interview with Rodney L. Everhart, available at http:/horizon.unc.edu.ts.vision/1999-11asp.

OECD (2005), E-learning in Tertiary Education. Where do we stand?, OECD, Paris.

Paquette, G., Ricciardi-Rigault, C., Bourdeau, C., Paquin, C. and Liégeois, S. (1995), Modelling a Virtual Campus Environment for Interactive Distance Learning, Proceedings of ED-Media International Conference, Graatz, Austria, june.

Pei-Luen, P.R., Qin, G., Li-Mei, W. (2008), Using mobile communication technology in high school education: Motivation, pressure and learning performance, Computers \& Education, 50 (1), 1-22, available at http://www.science direct.com/science/article/pii/S0360131506000601.

Stiglitz, J. and Walsh, C. (2002), Principals of macroeconomics (3rd ed.), New York, Norton. 
Tomescu, S.A. (2008), Învăţământ deschis la distanţă: abordare sociologică, Elearning Romania, 24, available at http://www.elearning.ro.

World Bank (2007), Building Knowledge Economies: Advanced Strategies for Development, Washington, DC. 